\title{
Description of a Twenty-Year Initiative to Bring STEM Career Exploration to Urban Minority Youth in Kansas City, Kansas: Multi-Sector Investment and Program Evolution
}

\author{
Joi Wickliffe ${ }^{1}$, Tawana Coates ${ }^{1}$, Jessica Rodas², Marcia Pomeroy², Ursula Carrillo², Maria Alonso Luaces ${ }^{2}$, \\ Nancy Twillman ${ }^{3}$, Ximena llabaca-Somoza', Mark Meyer ${ }^{2}$, Lisa Harlan Williams ${ }^{4}$, and Megha Ramaswamy ${ }^{1}$ \\ ${ }^{1}$ Department of Population Health and 2Office of Diversity and Inclusion, University of Kansas Medical Center, Kansas City, Kansas; ${ }^{3}$ Resource Development Institute, \\ Kansas City, Missouri; and ${ }^{4}$ University of Kansas Cancer Center, Kansas City, Kansas \\ Keywords: STEM, High School, Youth, Urban, Minority Youth, Program Description, Career Exploration, College Enrollment \\ Publication Date: August 10, 2020 \\ DOI: https://doi.org/10.15695/jstem/v3i2.04
}

\begin{abstract}
Since 1999, the Kansas K-12 Initiative has generated almost \$21 million from university, school district, private foundations, and federal sources to support the development of multiple STEM programs in Kansas City, Kansas. Program goals were to engage urban minority youth in STEM education, increase college readiness, and provide motivation for STEM careers. Over the 20-year period, these programs had 3,547 participants. Ninety percent of program graduates were racial and ethnic minorities. Almost all seniors ( $98 \%$ on average) enrolled in college, and $70 \%$ of students who declared a major, declared a STEM major. Programmatic findings demonstrate that STEM programming is widely supported, feasible, and effective on the measure of post-secondary education matriculation. This program description highlights the necessary evolution of programming over two decades with multiple funding sources, giving insight into sustained partnerships, commitment of staff, and long-term engagement of students.
\end{abstract}

\section{INTRODUCTION}

"Regrettably, far too many of our most able students are neither discovered nor developed, particularly those who have not had adequate access to educational resources, have not been inspired to pursue STEM, or who have faced numerous other barriers to achievement." (National Science Board, 2010, p5)

Science, technology, engineering, and math (STEM) careers are among the fastest growing careers in the United States (National Science Board, 2018). For decades, careers in this workforce have held the lowest overall unemployment rate (National Science Board, 2018). From physicians to mechanics, engineers, and computer technologists, STEM careers can provide an opportunity for financial stability and intellectual growth. The most recent data from the Bureau of Labor Statistics shows that 93 out of 100 STEM careers had wages above the national average (Fayer et al., 2017).

Despite modest gains in the last 25 years, racial and ethnic minority workers continue to be underrepresented in the STEM workforce (Chiappinelli et al., 2016). While Blacks make up $11 \%$ and Hispanics $16 \%$ of the workforce in the United States, they only represent $9 \%$ and $7 \%$ of STEM workers respectively (Funk and Parker, 2018). The proportion of individuals from racial and ethnic minority groups in college-level STEM occupations, although up from 9\% in 2003 to $13 \%$ in 2017, remains below their share of the college-educated workforce (17\%) (National Science Board, 2020). This is particularly true for fields with high-earning potential, including physicians and surgeons (11\%), pharmacists $(10 \%)$, dentists $(9 \%)$, physical therapists $(9 \%)$, and optometrists (5\%) (National Science Board, 2020).

In 1999, community members and leaders in the Kansas City Kansas Public School District noticed a lack of student interest and entry into STEM careers. These leaders, together with the University of Kansas Medical Center's (KUMC) Office of Diversity and Inclusion partnered to create the Kansas K-12 Initiative. Now in its 20th year, the Kansas K-12 Initiative has had nearly 3,500 participants from Kansas City, Kansas, providing opportunities for 
STEM education, college prep, and career exploration. Our objective was to describe the development and evolution of a 20-year old pipeline program that continuously aims to expose underserved youth to STEM careers, highlighting the programming, multi-sector investment, impact, and evaluation changes over time.

Efforts to diversify the STEM workforce pipeline have been active in the United States for more than 30 years (Allen-Ramdial and Campbell, 2014). Such efforts reflect the multilayered and complex nature of the problem, ranging from classroom interventions to mentorship programs, internships, and career exposure opportunities (Turkle and Papert, 1990). As opportunities to address the lack of diversity in STEM became available through national and federal funding, KUMC was one of the first institutions to receive funding to carry out programming in the local school district (Mervis, 1999). While participation in STEM pipeline programs have shown steady gains over time in college entry and completion for students traditionally not entering post-secondary education, other studies show how the literature on the evaluation of these programs are lacking (Knox et al., 2003; Chiappinelli et al., 2016).

Perhaps one of the most important outcomes of pipeline programs are the community partnerships built as a result of design and implementation of programming. STEM and other outreach programs that support both "peer networks" (Stanton-Salazar and Spina, 2005) and engagement of teachers, mentors, and community resources outside of the classroom have been shown to contribute to student success (Contreras, 2011). These peer networks, as well as the connections between program staff and students, are often hard to evaluate, but likely contribute to the biggest payoff for students.

As a result of these partnerships, whole communities become committed to students. Kansas City, Kansas is one such example, where a partnership among the school district, medical school, a local community college, students, and funders, created continuous and evolving STEM pipeline programs for the last 20 years.

\section{PROGRAM DESCRIPTION}

In this paper we focused on the foundational Kansas K-12 Initiative programs that included immersive student-centered activities and were separate from the school day.

Goals and Eligibility. There were four main goals that guided the development and enhancement of the Kansas K-12 Initiative:

To Engage Students in STEM Fields by Developing Unique Educational Opportunities, Early College Exposure, and Access to Mentors in STEM Careers. All programs extended beyond the traditional classroom. Program developers felt that in order to truly create a unique experience, it would have to be in a unique setting. Each program was held at a local community college, university, or academic medical center. What added to this unique experience was the quality of mentorship. Community mentors included individuals who were currently in STEM careers, teachers, or individuals who in some other way were closely invested in programs (Babineau, 2018; Pfeifer, 2002). Now in its 20th year, 68\% of mentors and teachers were former graduates of programs. Additionally, $70 \%$ of students who declared a major, declared a STEM major.

To Increase College Readiness and to Support Students on Their Journey to Post-Secondary Education. All programs provided some form of tutoring or homework help. Many of the program staff were teachers in the district and offered additional support to the students. One example of how teachers further engaged with students was through Saturday Science Academy (described below). Additionally, ACT prep and practice testing were provided. For summer programs, there was designated homework time to allow students to complete assigned work (some schools in the districts assigned summer work). Through some programs, students were exposed to day-to-day college life by being housed on college campuses in dorms.

To Target Urban Minority Youth in the Kansas City, Kansas Public School District and Create a Learning Environment Where All Students Can Share and Express Their Cultural Differences. The Kansas City Kansas Public School District is a very diverse district. Of 23,548 students, 51\% reported being Hispanic; 44\% are English language learners and; there are 63 different languages spoken at home (Kansas City Kansas Public Schools, 2019). Kansas K-12 Initiative programs incorporated opportunities for students to experience and appreciate the diversity in their communities. One example was "Multicultural Night." This program was designed so that all ethnic, racial, and cultural groups could express themselves and share pieces of their daily lives with the community (Anhalt et al., 2018; Talpade, 2018). This program was open to all community members, and it was held at a local university auditorium. Another program, Poetry Night, was held in the historic 18th and Vine Jazz district of Kansas City. This location has a rich history that is home to not only a jazz museum but also the Negro League Baseball Museum. Additionally, educational topics covered in programming often corresponded to local health needs, with the intent that local problems would resonate with student interest.

To Increase Students' Motivation in School and Learning by Offering Innovative Learning Activities and Decrease Barriers to Participation by Offering Stipends for Students. The idea was 
that by offering innovative learning activities, programming would increase students' motivation. For example, when teaching about the importance of mental health awareness, students needed to research information and share what they learned through a group-produced video. Program developers also knew that while increasing motivation through out-of-school learning activities, they would also simultaneously have to decrease barriers to participation. Youth that were recruited for programs came from socioeconomically disadvantaged backgrounds. At the conception of the Kansas K-12 Initiative, $17 \%$ of Kansas City, Kansas families lived at or below poverty level. To aid students under these circumstances, all programs provided a stipend, meals, and transportation to and from the programs. The program creators wanted to reduce as many barriers as possible to make participation easy for students. Participants in Saturday Science Academy received \$225 for completing all 15 sessions; Summer Science Research Academy participants received $\$ 750$ at the end of the summer program; Wednesday Media Project students were paid a stipend of $\$ 435$ if they attended all 15 sessions in this afterschool program; KUMC Summer Enrichment Camp participants received $\$ 750$ at the end of the summer program; and Research Institute participants were paid a stipend of $\$ 1000$.

Each program had roughly the same requirements for student recruitment:

1. The student needed to be a part of an economically disadvantaged background

2. The student must reside in the Kansas City Kansas Public School District

3. The student must have earned and maintained a 2.8 GPA

4. The student must have written an essay describing their interest in the program

Each participating school in the district had a designated program person who disseminated program information and distributed applications. Another informal method of recruitment was through siblings. Many families had all of their children participate in Kansas K-12 programs.

Kansas K-12 Initiative Programs. The Saturday Science Academy (SSA), developed in 1999, was the beginning of the 20-year pipeline program. SSA sessions began in October and 15 sessions were completed every other weekend throughout the school year. Students received over 80 hours of integrated STEM and language arts education (see Image 1). The curriculum was developed by teachers of the Kansas City Kansas Public School District, college students, community physicians, and other community leaders. There were 60 staff members and student mentors who were junior and senior high school students. The peer mentors worked closely with the staff members to organize and coordinate different activities. Special emphasis was placed on the mentorship aspect of the program as it was a core competency of Saturday Science Academy. Staff included previous SSA students and current SSA students who were seniors in high school (senior mentors). An important feature of mentorship was the tiered nature of mentors - expert faculty, teachers, former students, and current students. This provided a supportive environment for students and facilitated active learning.

Each year, middle and high school students explored a different health topic with an overarching theme. Topics were chosen based on alignment with global, national, and local relevance to students. For example, "emerging infectious diseases" dealt with racial/ethnic health disparities, given the racial/ethnic makeup of both students and the community where programming took place. Themes were then explored through five learning modules: bioethics, math, physiology, public health, and technology. The two groups came together during meal times, provided breakfast and lunch, and had a 30-minute physical activity time. Students worked on a special project throughout the year. At a "Family Breakfast and Demonstration Day" module instructors led students, parents and families through interactive activities. This allowed parents to interact with instructors and also provided an opportunity to do public service announcement work with the community. At the annual closing ceremony, the students showcased the work they had done throughout the year through technology-based platforms. Parents, student families, community, and community stakeholders attended the event to support students and learn from them.

To continue growing the skills learned and help transition students to the next phase of their education, The Summer Science Residential Academy (SSRA) was created in 2000 to give high school students a pre-college experience. The five-week program was hosted at the University of Kansas

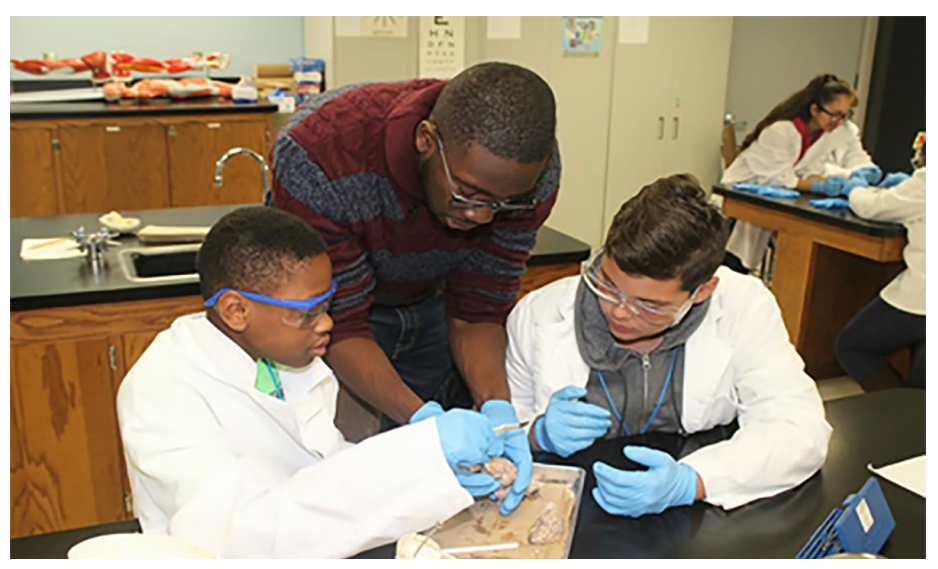

Image 1. Saturday Science Academy (SSA). Alumni and current medical student teaches brain anatomy and physiology to two middle school students through dissection and systems learning. 


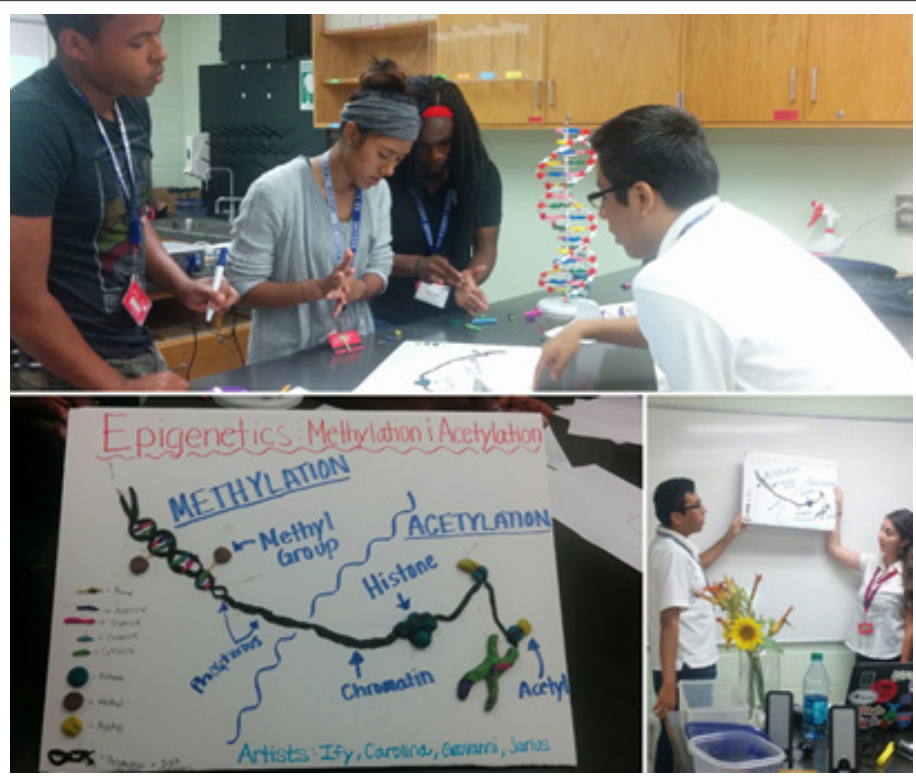

Image 2. Summer Science Residential Academy (SSRA). High school students learn and collaborate to build and present Epigenetics board outlining DNA methylation and acetylation model and process.

(KU) main campus in Lawrence, Kansas (about 38 miles from where students lived in Kansas City, Kansas). The students were housed on campus, walked to class alongside the college students, ate in the college cafeterias, and attended courses in college classrooms. Program developers felt that if students didn't have the experience of living on a college campus, they might not have a sense of whether it was going to be a good fit in the future. They also wanted to expose students to multi-cultural living in college and the rigor of inquiry. Students in this program also gained social and emotional competencies through "Multicultural Show" and "Poetry" events. Students participated in weekly workshops where they worked on culturally appropriate learning to enhance social and emotional learning. Students then showcased their work at an event.

To address the rigors of instruction in college, the SSRA curriculum was designed around more advanced topics: epigenetics, physiology, infectious disease, and human anatomy and dissection, for example (see Image 2). Not only were themes more advanced, students explored the topics more in depth and developed a more detailed understanding of scientific research. Camp students were also able to shadow a professional in a health career they were interested in pursuing.

One of the unanticipated benefits of this programming was that for participants who later went on to become teachers, they learned how to create curricula for high school students in creative ways and adapt to a non-authoritarian teaching style. Their practices reflected a larger code of conduct in SSRA and SSA programming. Teachers of programs also modified their practices over the years to better fit this style.

The Wednesday Media Project (WMP) was developed

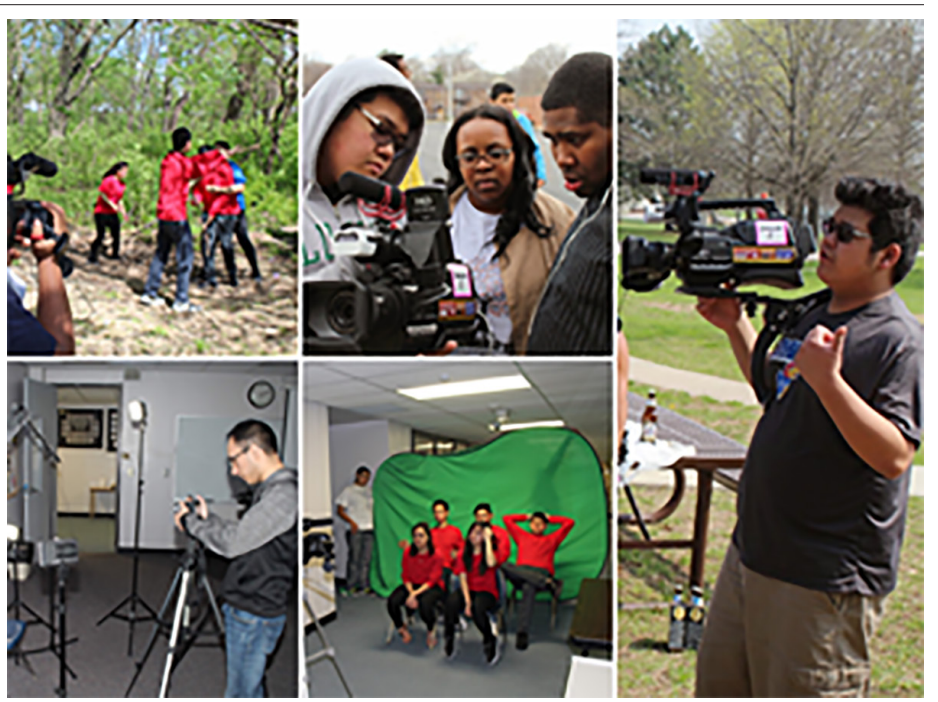

Image 3. Wednesday Media Project (WMP). Students work with professional artists and technology instructors to create short films on social and health disparity issues in their community.

in 2004 to provide an opportunity for high school students to express cultural health and social justice issues using music, film and scripting (see Image 3). Thirty high school students from the Kansas City Kansas Public Schools were selected to participate each year. The school district has early release on Wednesdays for staff development, therefore the WMP was in session from 1-5pm. To express interest in WMP activities, students just had to check off a box at the top of an application that listed all school-year programming. Held at the local community college, WMP was unique in that it was a school-year-long activity.

Participants were mentored by professional artists, medical researchers, and staff in the media services department from Kansas City Kansas Community College (KCKCC). Having a professional working artist or researcher lead the students, especially if that was a person of color with whom the students could identify with, allowed students to develop creative ways of viewing research topics and professional mentorship from experts in the field (Daugherty, 2013; Egalite and Kisida, 2018; Goldhaber et al., 2015). Students also worked with a full-time technology consultant, who offered insight and direction for completing projects. The curriculum covered health disparities, social justice, and cultural values, and students used music, scripting, and research to develop short films. Participants worked together to make short films that covered a range of topics such as sexual harassment, the effects of domestic violence, and how to give support for mental health conditions. These videos can be viewed at this URL: https://sites.google.com/site/wednesdaymediaproject/home. The students' work was presented to family and the community, and every year films were aired on a local cable television channel. 


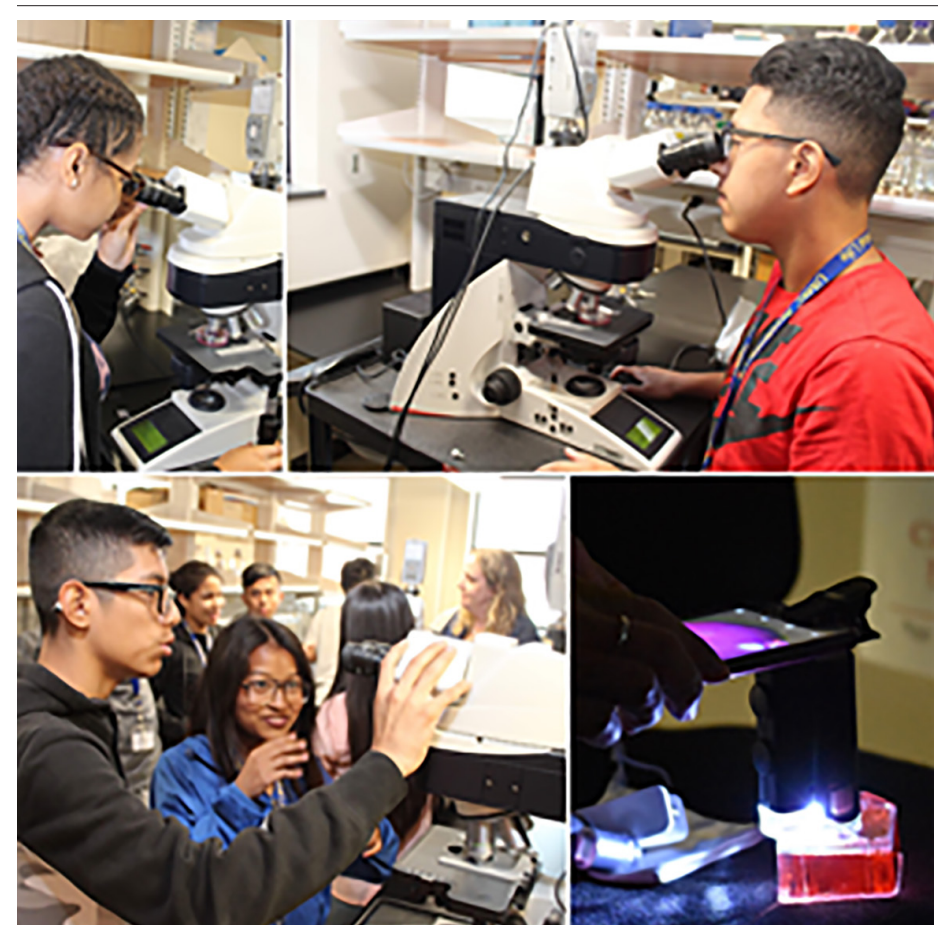

Image 4. Summer Enrichment Camp (SEC). Students visit University of Kansas Cancer Center lab to view HeLa cells after learning and completing research project on Henrietta Lacks and her contribution to the medical community.

The KUMC Summer Enrichment Camp (SEC) began in 2008. This program was similar in structure to that of the SSRA, but was held at KUMC for those students who could not stay on the main KU campus, again, 38 miles away. This five-week summer program hosted 30 high school students in grade levels 9-11. Students were required to attend the program five days a week on the KUMC campus, with courses held from 9am-3pm each day. Students participated in the same multicultural programming as SSRA students to boost social and emotional learning. This camp was also geared towards students who specifically wanted to pursue a medical career, whereas SSRA was geared towards students who were interested in STEM, more broadly. While there was crossover between both programs, they each had their own specific curricula. The SEC curriculum included a Kaplan ACT preparation course in later years (2017 on) and STEM learning modules. Homework blocks incorporated within the camp included tutoring on STEM topics and also allowed students to complete required summer homework assignments. This program was especially unique in that each educational theme had an associated field trip. For example, for the nutrition and health theme, students visited local markets and created geographic information system (GIS) mapping of different neighborhoods describing the food deserts in the community (see Image 4). Program leaders wanted to incorporate a residential component of the program into the SEC. In 2017, they received funding from Avila University so that participants could live in college

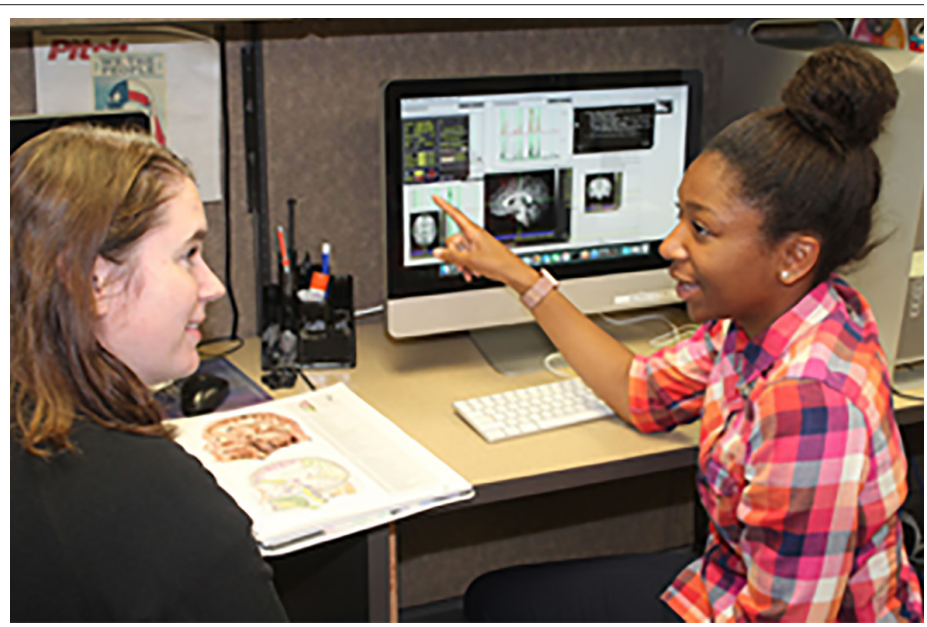

Image 5. Research Internship (RI). Research mentor and intern discuss brain activity and translation of data.

dorm rooms in the $\mathrm{KC}$ metro area for the duration of the camp.

The Research Internship (RI) program began in 2009 . This program was created to give students the opportunity to complete research projects alongside a research mentor (see Image 5). This six-week summer program was intended for graduating seniors going into their freshman year of college, but rising junior students who showed a strong interest in research were also eligible. The program was designed to host 10 students per year with a range of 10-14 students in all program years. Each research mentor was a KUMC faculty or staff member. The research faculty submitted project proposals to the program administrators, and during orientation the students chose mentors and research teams. During orientation, each participant was required to complete research integrity training before joining their research team. The research mentors were expected to work with the students five days a week from 9am-3pm; help students conduct a literature review (offered in conjunction with KUMC's medical librarians); and expose students to new research methodologies, including data collection and analysis. At the end of the internship, students presented their research at a closing ceremony to family, community members, and program stakeholders. Some of the students went on to publish with their research teams or get jobs as paid research interns. Like other programs, students were exposed to multicultural content to increase social and emotional learning in the process of the internship.

Staff. There were several core staff and ongoing champions that made continuous programming possible. The Kansas K-12 Initiative had the same program Director for 20 years. The director served as the programs' key champion, resource-generator, connection to families and communities. The director knew students, parents, and siblings by first name, telephone numbers, information about community events, and worked to marshal resources for programming 
and families as needed. The director's salary was paid by KUMC, though office time was divided as needed among the KUMC campus, community college partner campus, and out in the community. This director retired just this year, handing off programming to a former graduate of Kansas K-12 Initiative programs. A second key staff member was the Senior Coordinator, a position held by the same person since 1999. This position functioned like a school district liaison, serving as a bridge between the school district and the Kansas K-12 Initiative, with responsibilities including dayto-day programming and working with teachers and students on recruitment. After recruitment, the focus of this position was on program coordination. The third key staff position was that of Operations Manager. The person who held this position with the Kansas K-12 Initiative did so for 20 years. This role included transportation for students to and from programming, photo documentation of program events (see Images 1-5, for example), inventory, purchasing, printing, and any day-to-day assistance, as needed. This person became a true point of contact for the students, because the operations manager saw students consistently more than any other staff member - picking up students and dropping them off at their homes each day - creating a unique bond.

It cannot be understated that these positions were critical to program success, to the extent that all programming was run by these staff members; that every student who participated in programming came to know these staff members and interact with them on a daily basis; and that all positions were filled by people who had dedicated large chunks of their careers to the Kansas K-12 initiative. Notably, there was no turnover of the three key staff members for 20 years. The director credited this to engaging in the following practices: pay staff as much as you can; treat them like family; allow for flexibility; and be outcomes-oriented rather than counting hours in the office. The salaries of these key staff members were largely paid by KUMC. While continuity of key staff members was a feature of the Kansas K-12 Initiative, a rotating set of key players was also always present.

These included program Mentors as described above in the Kansas K-12 Initiative program description, many of whom were former program participants or "near peers." Each year, roughly two-thirds or more of program mentors were former participants in the Kansas K-12 Initiative. We felt that our former participants, who later became mentors and teachers, integrated a long-term understanding of students' life and academic experiences. Being an underserved student, now a young adult mentor or teacher, provided a connection that could not be duplicated outside of their authentic life experience. Programming was always supported by Faculty and Staff Grant Writers - most often the director, but also faculty at KUMC. As described in a subsequent section, the director leveraged funds from KUMC and local foundations to almost continuously support programming, while faculty leveraged federal funds to support novel program additions, for example, in the case of Science Education Partnership Awards. KUMC faculty also served as mentors, especially in the more directed research internship experiences. A rotating group of University Leaders, but always the Executive Vice Chancellor of the medical school campus, the Associate Dean for the Office of Diversity and Inclusion at the medical school, and the Dean of Science, Math, and Technology at the community college, supported programming financially and in partnership with the community at large. Similarly, Kansas K-12 Initiative staff built a solid bridge between KUMC and Kansas City Kansas Public School District Leadership, a partnership that has

Table 1. Kansas K-12 Initiative Funding in Kansas City, Kansas.

\begin{tabular}{llll}
\hline Funder & Years of funding & Amount per year & Programs served \\
\hline University of Kansas Medical Center & 1999 -present & $\$ 234,500$ & $\begin{array}{l}\text { SSA,WMP, salaries for } 3 \text { full-time staff } \\
\text { members, external evaluation }\end{array}$ \\
Health Resources and Services Administration & $1999-2007$ & $\$ 250,000$ & $\begin{array}{l}\text { SSA, SSRA, WMP } \\
\text { Bank of America }\end{array}$ \\
Ewing Marion Kauffman Foundation & $2003-2007$ & $\$ 50,000$ & SSA \\
National Institutes of Health & 2008 -present & $\$ 725,000$ & SSA, SEC, WMP, RI \\
Kansas Health Foundation & $2009-2012$ & $\$ 1,000,000$ & SSA, WMP \\
DST Systems, Inc. & $2010-2016$ & $\$ 50,000$ & General programming \\
Kansas City Kansas Public School District & $2011-$ present & $\$ 5,000$ & SSA, transportation for summer \\
21st Century Community Learning Centers & $2011-2019$ & $\$ 20,000$ & SSA,SSRA, WMP \\
Kansas City Kansas Community College & $2012-2019$ & $\$ 150,000$ & SSA, WMP \\
Health Forward Foundation & $2015-2018$ & $\$ 200,000$ & SEC \\
University of Kansas Cancer Center & $2016-2019$ & $\$ 140,000$ & RI \\
Kansas IDeA Network of Biomedical Research Excellence & 2018 -present & $\$ 3,500$ & RI \\
Frontiers University of Kansas Clinical and Translational & 2018 -present & $\$ 1,000$ & RI \\
Science Institute & & $\$ 35,000$ & \\
\hline
\end{tabular}


been sustained for 20 years across multiple programs. The district Superintendent has been a key player, even as the person holding that position has changed over the years. But other essential players have included school principals, Health Careers Pathways staff, school Career Technical Education staff members, teachers, and community coordinators at the schools.

Funding. Fourteen funders have provided about $\$ 21$ million over the past 20 years to support the Kansas K-12 Initiative (see Table 1), which represents about a $\$ 6,000$ investment per participant in each program. This funding included a mix of university support, money from local private foundations, and federal sources. Like many long-running initiatives, funds have been spread across programs as needed. On the whole, university funding was obtained through annual meetings with leadership. Foundation funding typically ran on a one-two year application cycle, and federal funds were generally obtained for a five-year period. The director of the Kansas K-12 Initiative was largely involved in obtaining funding, though federal grants were often applied for by faculty in concert with the director. Occasionally, funds would drop off, and other larger community funders would step in. Because the Kansas City philanthropic world was small and the director was well-networked, word got around about program reach, impact, and need.

It is also worth noting that Kansas K-12 Initiative programming could not have continued over the years without substantial in-kind contributions from community entities. In-kind contributions included all of the group meeting spaces, lab spaces, and lab equipment donated by the community college; transportation for some programming donated by the school district; media equipment and lab space donated by the community college; and individual computers for high school students to use during the summer donated by the school district. These resources really speak to how community sees and values programming.

\section{EVALUATION METHODS}

Evaluation of Kansas K-12 Initiative programs was conducted internally from 1999-2008. For these years, the only data available were number of program participants, number of program seniors, and college entrance rate for seniors (starting in 2003). A "program participant" was a student who participated in any one of the five educational programs described in this article. Some students participated in multiple programs, so the total number of program participants does not represent individuals. We know that among program graduates, on average students participated in 1.68 Kansas K-12 Initiative programs (range 1-3). From 2009 onward, evaluation was conducted by a local independent evaluator, Resource Development Institute (RDI), and paid for by KUMC. Because RDI evaluated programs for the last 10 years, there was a fair amount of consistency in evaluation. However, evaluation outcomes varied by funder, depending on who was funding which program in a given year. Because program staff had developed a trusting relationship with the school district for ten years prior to external evaluation, the district was forthcoming with data on student GPAs. For some years, evaluators assessed student knowledge and interest in STEM through surveys (2008-2014). For years 2009-2019, data available were number of program participants and student achievement, across the five programs described in this paper and over time. Data on graduating seniors were also collected for some years. Where there were minor discrepancies in reports - often in the number of students, where reporting was off by 1-5 students, we reported either on the lower number of students or on the report with the most complete evaluation data. In some years, summer graduates were counted in the previous year of reporting, but we tried to follow as closely as possible reports from the external evaluator on inclusive years, e.g. "2009-2010."

In addition to program participant data, staff maintained internally and continue to maintain a database of seniors who participated in the college preparation programs (SSA, SSRA, SEC) ( $\mathrm{N}=364$, from years 2002-2018, with an average of about 18 graduating seniors per year). Data collected for this internally-maintained database were demographics

Table 2. Kansas K-12 Initative Student GPA Benchmarks Achieved by Program.

\begin{tabular}{llll}
\hline $\begin{array}{l}\text { Programs } \\
\text { evaluated }\end{array}$ & $\begin{array}{l}\text { Benchmark } \\
\text { GPA }^{2}\end{array}$ & $\begin{array}{l}\text { \% of students } \\
\text { to make Math } \\
\text { benchmark }\end{array}$ & $\begin{array}{l}\text { \% of students to } \\
\text { make Reading } \\
\text { benchmark }\end{array}$ \\
\hline SSA, SSRA, WMP & & \\
\hline 2012 & 2.4 & $60 \%$ & $78 \%$ (English) \\
2013 & 2.4 & $70 \%$ & $77 \%$ (English) \\
2014 & 2.4 & $69 \%$ & $78 \%$ \\
2015 & 2.0 & $89 \%$ & $91 \%$ \\
2016 & 2.0 & $94 \%$ & $94 \%$ \\
2017 & 2.0 & $92 \%$ & $88 \%$ \\
2018 & 2.0 & $81 \%$ & $86 \%$ \\
\hline SEC and RI & & & $100 \%$ \\
\hline 2015 & 2.0 & $90 \%$ & $93 \%$ \\
2016 & 2.0 & $83 \%$ & $93 \%$ \\
2017 & 2.0 & $83 \%$ & \\
\hline
\end{tabular}

${ }^{1}$ Evaluators measured data across three programs, where noted, and two programs where noted. Any missing years means that GPA data were not collected in those years.

${ }^{2}$ Benchmarks changed according to program goals and funders' requests. When the 2.4 GPA benchmark was chosen, it reflected evaluation of programs designed to prepare students for the medical and health sciences, specifically. When new funding supporting a STEM focus of programming more broadly, the GPA benchmark was moved to 2.0, a benchmark set by the Kansas Board of Education.

${ }^{3}$ After 2013, Reading was the benchmark measured instead of English. 


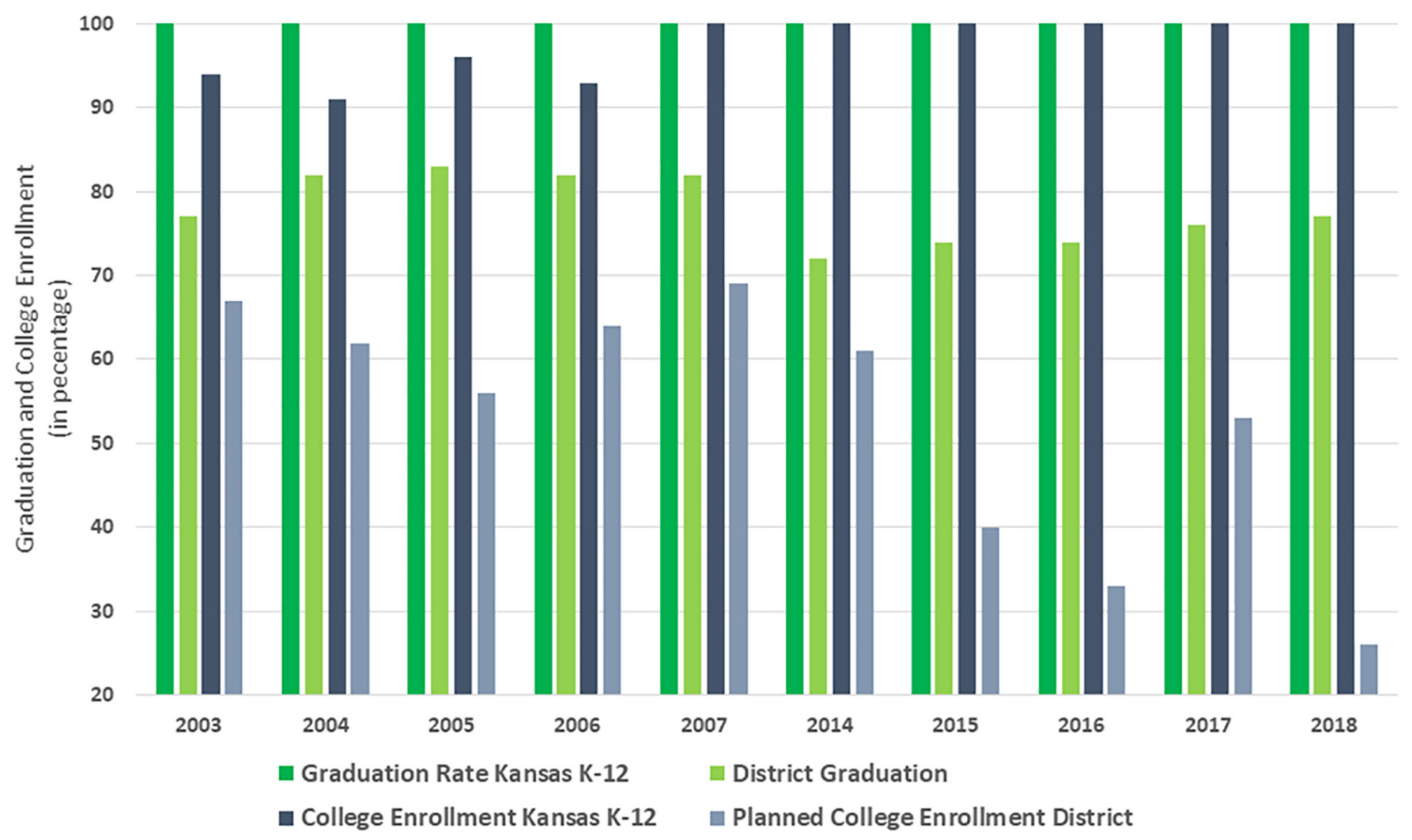

Figure 1. Kansas K-12 Initiative Graduation and College Enrollment. SSA was the only program for whch graduation data were provided. As a reminder, SEC does not include seniors, and RI has a primary focus of post graduate seniors entering college. Where available, planned college enrollment for the district was included. Additionally, gaps in data points represent places where data were not collected or available across all measures. All school district comparison data came from the Kansas State Department of Education: https://datacentral.ksde.org/report_gen.aspx

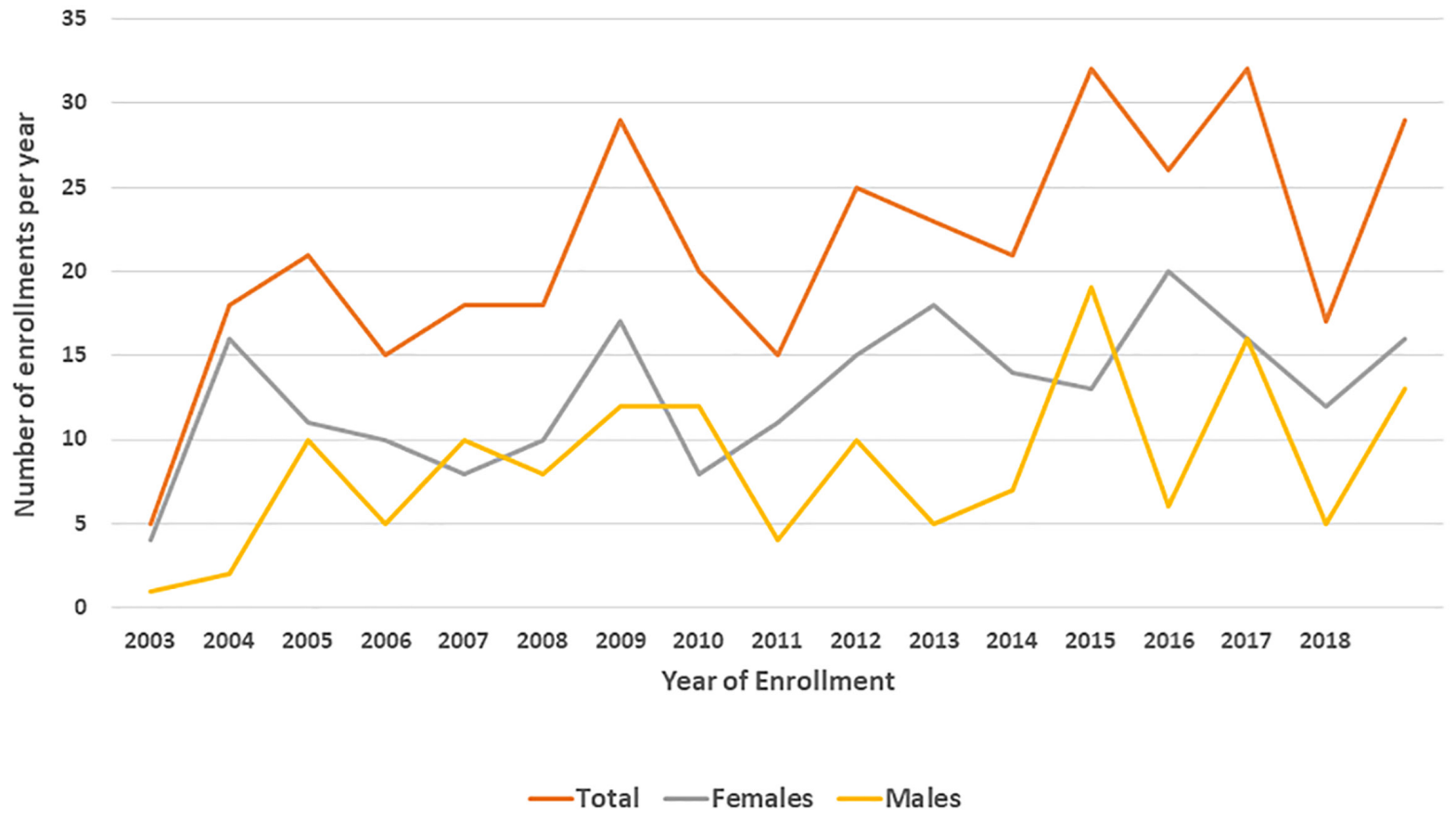

Figure 2. Kansas K-12 Initiative College Enrollment Trends by Gender, 2002-2018. 
Table 3. Racial/Ethnic Breakdown of Kansas K-12 Initiative Graduates by Gender

\begin{tabular}{lcccccc}
\hline Race/ Ethnicity & \multicolumn{2}{c}{ Female } & \multicolumn{2}{c}{ Male } & \multicolumn{3}{c}{ Total } \\
& $\mathbf{N}$ & $\mathbf{\%}$ & $\mathbf{N}$ & $\mathbf{\%}$ & $\mathbf{N}$ & $\mathbf{\%}$ \\
\hline Black & 81 & $55 \%$ & 66 & $45 \%$ & 147 & $40 \%$ \\
Hispanic & 79 & $63 \%$ & 47 & $37 \%$ & 126 & $35 \%$ \\
Asian & 40 & $66 \%$ & 21 & $34 \%$ & 61 & $17 \%$ \\
White & 17 & $68 \%$ & 8 & $32 \%$ & 25 & $6.9 \%$ \\
Asian/Black & 2 & $67 \%$ & 1 & $33 \%$ & 3 & $0.8 \%$ \\
Pacific Islander & 0 & $0 \%$ & 2 & $100 \%$ & 2 & $0.5 \%$ \\
Total & $\mathbf{2 1 9}$ & $\mathbf{6 0 \%}$ & $\mathbf{1 4 5}$ & $\mathbf{4 0 \%}$ & $\mathbf{3 6 4}$ & $\mathbf{1 0 0 \%}$ \\
\hline
\end{tabular}

(race/ethnicity and sex); enrollment into two- or four-year colleges/universities; and enrollment and/or graduation with STEM majors. Data were collected by the program director and through direct follow-up of past participants.

\section{RESULTS}

Saturday Science Academy had an average of 124 participants per year (range 20-255) with a total of 2,374 participants over 20 years; Summer Science Residential Academy had an average of 31 participants per year (range 25-44; total 564 participants); Wednesday Media Project had an average of 28 participants per year (range 19-31, total 278 participants); Summer Enrichment Camp had an average of 26 participants per year (range 24-30, total 208 participants); and Research Internship had an average of 11 participants per year (range 10-14, total 123 participants).

While data vary from year to year, between $60-94 \%$ of students were at or above the GPA benchmark set for "high achievement." As indicated in Table 2, that benchmark was set at a GPA of 2.0 or 2.4 depending on the year. Among seniors, $100 \%$ graduated in four years. Between $93-100 \%$ of senior program participants enrolled in college over time. As indicated in Figure 1, this was approximately 1.5-4 times the rate of students in the school district who planned to go to college and did not participate in programming.

Table 3 shows the racial/ethnic breakdown of program graduates by gender $(\mathrm{N}=364)$. On the whole, program graduates were similar along racial, ethnic, and gender lines to program participants, data that were collected annually by external evaluators but not reported here $(\mathrm{N}=3,547)$. Among program graduates, most students were Black $(\mathrm{N}=147$, $40 \%)$ or Hispanic $(\mathrm{N}=126,35 \%)$. Sixty percent were female $(\mathrm{N}=219)$ and $40 \%$ were male $(\mathrm{N}=145)$.

As shown in Figure 2, there was a slight upward trend in college enrollment over time, with females slightly outperforming males. Among program graduates, 20.3\% ( $\mathrm{N}=74)$ enrolled in two-year colleges, and $74.5 \%(\mathrm{~N}=271)$ in fouryear colleges. There was no information for $5.2 \%$ (19) stu-
Table 4. Kansas K-12 Initiative Graduate Enrollment into Universities

\begin{tabular}{llc}
\hline University/College name & $\begin{array}{l}\text { \# of Students } \\
\text { enrolled }\end{array}$ & \% \\
\hline College enrollment one hour driving distance from Kansas City, Kansas \\
Kansas City, Kansas Community College & 63 & 31.5 \\
University of Kansas & 59 & 29.5 \\
University of Missouri, Kansas City & 28 & 14.0 \\
Johnson County Community College & 15 & 7.5 \\
Donnelly College & 10 & 5.0 \\
Emporia State University & 8 & 4.0 \\
Avila University & 3 & 1.5 \\
Park University & 3 & 1.5 \\
University of Missouri, Kansas City, & 3 & 1.5 \\
School of Medicine & & 1.0 \\
Rockhurst University & 2 & 1.0 \\
University of Missouri, Kansas City, & 2 & 1.0 \\
School of Dentistry & & 0.5 \\
Lincoln University, Jefferson City, MO & 2 & 0.5 \\
Penn Valley Community College & 1 & 40.4 \\
Nazarene College & 1 & \\
\hline College enrollment out of state & & \\
Out of state universities and colleges & 147 & \\
\hline Missing data & & \\
No data on which university or college & 17 & \\
\hline Total & $\mathbf{3 6 4}$ & \\
\hline
\end{tabular}

dents. Among data available, $18 \%$ of students who enrolled in two-year colleges transferred to a four-year university. As shown in Table 4 , most students $(55 \%)$ of 364 chose either a two- or four-year college within a one hour driving distance of Kansas City, Kansas. Figure 3 shows how many students declared STEM majors $(\mathrm{N}=189)$ vs. those who did not $(\mathrm{N}=80)$, or whose majors were unknown $(\mathrm{N}=95)$. Seventy percent of students who did declare a major, declared a STEM major. The most popular STEM major category was health sciences $(\mathrm{N}=119)$.

\section{DISCUSSION}

In this paper we aimed to describe a 20-year K-12 Initiative in Kansas City, Kansas that sought to engage underserved youth in STEM career exploration. Programs were designed with four goals in mind that ultimately provided an immersive health science education experience catered to high school youth in the Kansas City Kansas Public School District outside of regular school hours. While programs are still ongoing, this report provides a snapshot of the last 20 years. Figure 4 provides an overview of program inputs, activities, goals, and lessons learned.

The first goal of the Kansas K-12 Initiative was to engage students in STEM learning with educational, college 


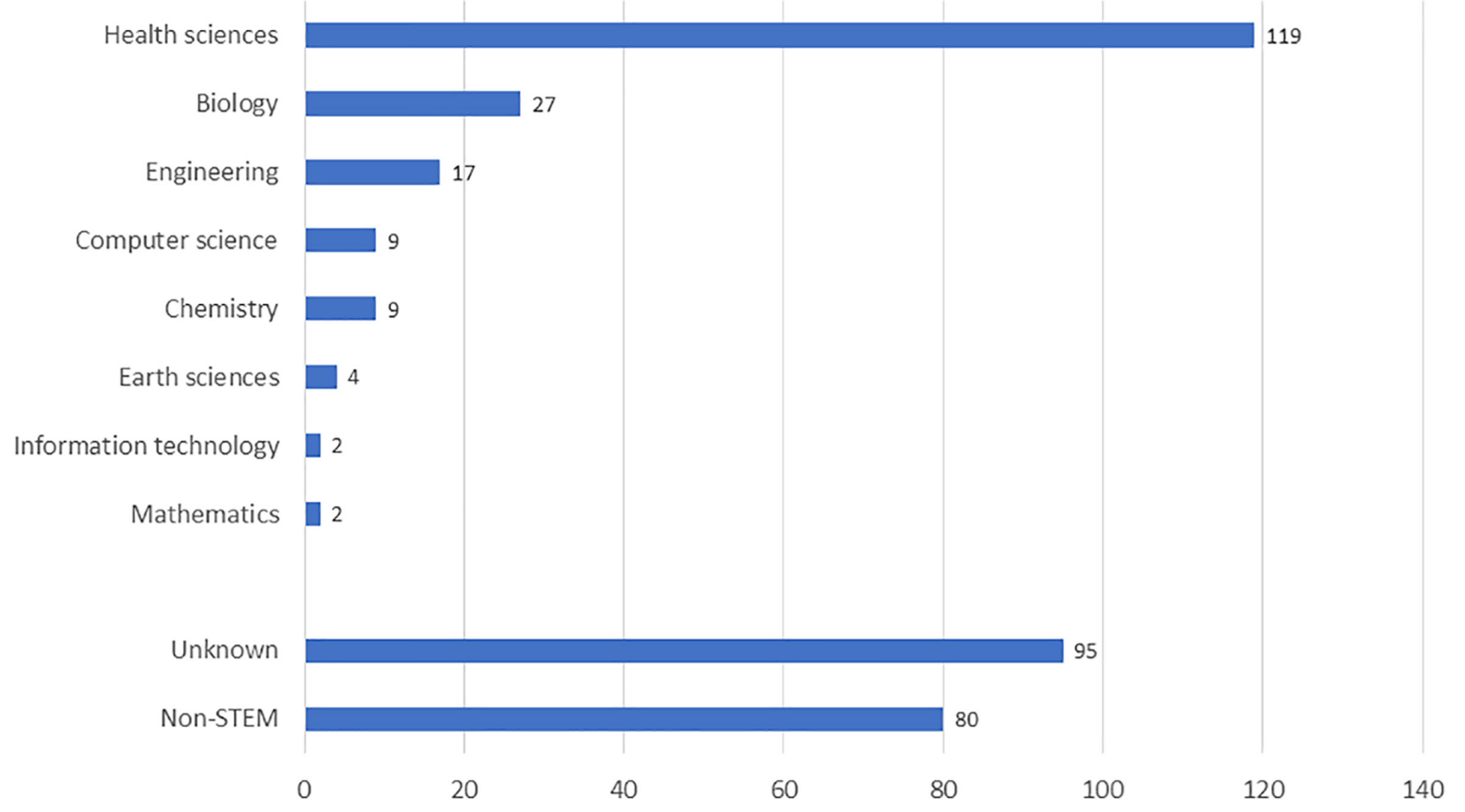

Figure 3. Kansas K-12 Initiative College Majors.

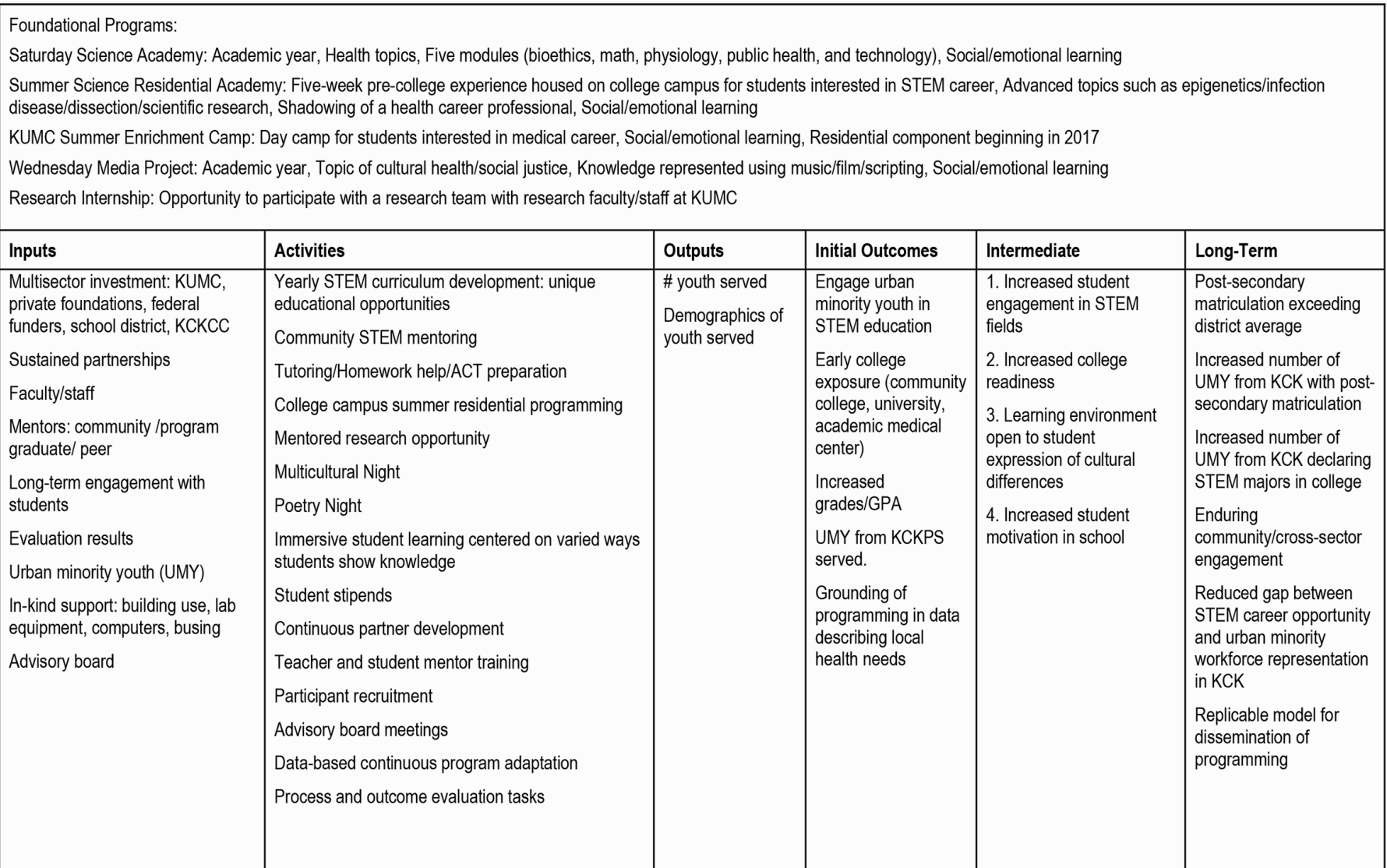

Lessons Learned: OPPORTUNITIES

Sustainability, staff retention, multisectoral funding, rigorous programming, peer/professional mentor model

\section{Lessons Learned: CHALLENGES}

Seeking funding, changing metrics over time, longitudinal follow-up for STEM career entry

Figure 4. Kansas K-12 Initiative Program Logic Model. 
preparatory, and mentorship experiences. Over 20 years, we served 3,547 students. STEM career exploration provides many potential benefits to those from backgrounds traditionally underrepresented in the health sciences - for example, racial and ethnic minorities, children of recent immigrants, and those for whom they might be the first in their families to attend college. In addition to intellectual growth, a career in a STEM field could provide opportunities to increase economic stability (Fayer et al,. 2017). Even though there are higher paying STEM career fields, like in computer science, medicine, or engineering, the median income for someone with less than a bachelor's degee in a STEM field is $\$ 54,745$ (Pew Research Center, 2018).

The second goal was to get students ready for college. On the whole, more students who participated in the Kansas K-12 Initiative compared to students in the school district who did not participate, graduated from high school and enrolled in college. For the years we had data, between 1.5-4 times as many Kansas K-12 Initiative graduates planned to enroll in college compared to students in their school district. In the 2018-2019 school year, 97\% of Kansas K-12 Initiative students were accepted into college, compared to only $42 \%$ of students in the previous year who were "successful," that is, earned an industry certification, post-secondary certificate degree, or were enrolled in post-secondary education in the two years after high school (Kansas State Department of Education, 2020).

The third goal was to reach urban minority youth. All youth served by the Kansas K-12 Initiative in Kansas City, Kansas were from an urban school district; $51 \%$ of students in the district were Hispanic, 27\% Black; 11\% White; and 7\% Asian; and 11\% (Kanas City Kansas Public Schools, 2019). This diversity was also reflected in program staff and mentors. More than two-thirds of program participants from the district returned as mentors to future cohorts of students (Contreras, 2011; Stanton-Salazar and Spina, 2005). The Kansas K-12 Initiative was unique in that it made sure to engage students' cultural identities in all programming (Anhalt et al., 2018; Talpade, 2018). Concluding programs with a celebration of cultural diversity was a positive way to ensure all students and families are encouraged to appreciate different backgrounds. Program developers appreciated this in the beginning and continued to infuse programming with a celebration of students' heritage and diversity.

The fourth goal was to motivate students to pursue STEM careers with innovative learning activities and decrease barriers to participation by providing stipends for students' time. The best measure of motivation for us was whether or not students entered STEM careers. We didn't have those data; however, we know that among students who declared a major, 70\% chose a STEM major. This is almost four times higher than the $18 \%$ for first-year undergraduates in the United States (National Science Board, 2016). Programming also provided meaningful stipends to students. Many of the students who participated in programming would not have been able to participate in summer programming in lieu of a part-time summer job to help support their families. So the stipends were critical to enrollment and retention in programming (Carrick et al., 2016).

Over 20 years, the Kansas City, Kansas community, as well as federal funders, invested heavily in local programming. As noted in our discussion of funding, even beyond the annual investment of nearly $\$ 1$ million per year, the partners provided a lot of in-kind support to keep programming going. If the total 20 -year investment of $\$ 21$ million were spread over each of the almost 3,500 participants, that amounts to about $\$ 6,000$ per student. This is a significant investment, but one that is likely to pay off, and is only a start in bridging the gap between STEM career opportunity and representation of a diverse workforce. This amount pales in comparison to, for example, our criminal justice investment in young people of color in an era of mass incarceration, where more young people are in jails and prisons compared to universities. In 2015, Kansas leaders created a workforce with the goal of seeking alternatives to detainment for young people. Lack of resources are forcing juveniles to be moved from place to place on the state's dime at a cost of $\$ 50,000$ per year, per youth, to live in a non-secure group home; or placed in juvenile corrections, costing $\$ 89,000$ per youth (Pew Charitable Trust, 2017). This money could be better invested in educational programming for young people that has much more impactful payoff in the workforce than imprisoning them (Viloro, 2014)

While this article reports on number of participants, academic achievement, and college enrollment, there were no systematic measures of participants' involvement with STEM careers after college entry. There are hundreds of graduates that have returned to the community to work in the very programs and schools, and this is a strength of the Kansas K-12 Initiative that needs to be evaluated. Data that could potentially strengthen the impact of the Kansas K-12 Initiative programs include students' retention in STEM majors in college, number of STEM jobs obtained after college, professional incomes, and the student loan debt acquired through pursuing STEM careers.

In conclusion, we demonstrated that pipeline programs for underserved urban youth in Kansas City, Kansas are very well supported in the community, can be sustained for over two decades, and serve many students. Room for improvement exists, as this career field continues to lead to economic growth. One notable strength of the Kansas City experience is how close the Kansas K-12 Initiative worked with the students. For 20 years the director and core staff made it their mission to become integrated into the community. This may be an area we may all improve on when trying to impact the lives of youth. 


\section{AUTHOR INFORMATION \\ Corresponding Author}

Megha Ramaswamy, PhD, MPH. Department of Population Health, University of Kansas School of Medicine, 3901 Rainbow Blvd, MS 1008, Kansas City, KS 66160. (913) 588-1053.mramaswamy@kumc.edu

\section{Author Contributions}

The manuscript was written through contributions of all authors. All authors have given approval to the final version of the manuscript.

\section{ACKNOWLEDGMENTS}

Over 20 years, there are many people to acknowledge our funders (listed in Table 1), our champions at universities and schools, dedicated staff, and of course, the students. We would like to acknowledge Dr. Patricia Thomas, the Principal Investigator of the Science Education Partnership Award (2009-2012), who passed away in 2015. This article is especially dedicated to Mr. Douglas Walker, who passed away in 2019. He gave everything to these programs and the students. Finally, all of the authors write this as a retirement gift to co-author and 20-year Director, Ms. Marcia Pomeroy.

\section{ABBREVIATIONS}

GIS: Geographic Information System; KCKCC: Kansas City Kansas Community College; KU: University of Kansas; KUMC: University of Kansas Medical Center; RDI: Resource Development Institute; RI: Research Internship; SEC: KUMC Summer Enrichment Camp; SSA: Saturday Science Academy; SSRA: Summer Science Residential Academy; STEM: Science, Technology, Engineering, and Math; WMP: Wednesday Media Project

\section{REFERENCES}

Allen-Ramdial, S. A., and Campbell, A. G. (2014). Reimagining the pipeline: Advancing STEM diversity, persistence, and success. Bioscience, 64(7), 612-618.

Anhalt, C. O., Staats, S., Cortez, R., and Civil, M. (2018). Mathematical modeling and culturally relevant pedagogy. In Cognition, metacognition, and culture in STEM education (pp. 307-330). Springer, Cham.

Babineau, K. (2018). Closing the Gap: An overview of the literature on college persistence and underrepresented populations. Cowen Institute.

Carrick, T. L., Miller, K. C., Hagedorn, E. A., Smith-Konter, B. R., and Velasco, A. A. (2016). Pateways to the geosciences summer high school program: A ten-year Evaluation. Journal of Geoscience Education, 64(1), 87-97.
Contreras, F. (2011). Strengthening the bridge to higher education for academically promising underrepresented students. Journal of Advanced Academics, 22(3), 500-526.

Chiappinelli, K.B., Moss, B.L., Lenz, D.S., Tonge, N.A., Joyce. A., Holt, G.E., and Woolsey.T.A. (2016). Evaluation to improve a high school summer science outreach program. Journal of Microbiology and Biology Education, 17(2), 225-236.

Daugherty, M. K. (2013). The prospect of an" A" in STEM education. Journal of STEM Education: Innovations and Research, 14(2).

Egalite, A. J., and Kisida, B. (2018). The effects of teacher match on students' academic perceptions and attitudes. Educational Evaluation and Policy Analysis, 40(1), 59-81.

Fayer, S., Lacey, A., and Watson, A. (2017). STEM Occupations: Past, Present, and Future. U.S. Bureau of Labor Statistics. Retrieved from https://www.bls.gov/spotlight/2017/science-technology-engineering-and-mathematics-stem-occupations-past-present-and-future/home.htm

Goldhaber, D., Theobold, R., and Tien, C. (2015). The theoretical and empirical arguments for diversifying the teacher workforce: A review of the evidence. Center for Education Data and Research. Policy Brief, WP \#2019-9. Retreived from http://www. cedr. us/papers/working/CEDR $\%$ 20WP, 202015(9).

Kansas City Kansas Public Schools. (2019). KCKPS At a glance. Retrieved from https://kckps.org/kckps-at-a-glance/

Kansas State Department of Education. (2020). Kansas Report Card 2018-2019. Retrieved from http://ksreportcard.ksde. org/ccr.aspx?org_no $=$ D0500\&rptType $=2$

Mervis, J. (1999). Graduate students head to class as new NSF teaching fellows. Science, 29 October. Retrieved from http://www.science $\neg$ mag.org/careers/1999/10/grad-students-head-class-new-nsf-teaching-fellows

National Science Board. (2020). Science and Engineering Indicators 2020: The State of U.S. Science and Engineering. NSB-2020-1. Alexandria, VA: National Science Foundation. Retrieved from https://ncses.nsf.gov/pubs/nsb20201/

National Science Board (2018). Science and Engineering Indicators 2018 Digest. NSB-2018-2. Alexandria, VA: National Science Foundation. Retrieved from https://www.nsf.gov/ statistics/2018/nsb20181/digest/sections/preface

National Science Board (2010). Preparing the Next Generation of STEM Innovators: Identifying and Developing our Nation's Human Capital. NSB-10-33.Alexandria, VA: National Science Foundation. Retrieved from https://www. nsf.gov/nsb/publications/2010/nsb1033.pdf

Pew Charitable Trust. (2017). Kansas' 2016 Juvenile Justice Reform. Retrieved from https://www.pewtrusts.org/en/research-and-analysis/issue-briefs/2017/06/kansas-2016-juvenile-justice-reform 
Pew Research Center. (2018, January 1). Women and Men in STEM Often at Odds Over Workplace Equity. Retrieved from https://www.pewsocialtrends.org/2018/01/09/women-and-men-in-stem-often-at-odds-over-workplace-equity/

Pfeifer, S. E. (2002). The benefits of establishing a student/alumni mentoring program. The Mentor: An Academic Advising Journal, 4(4).

President's Council of Advisors on Science and Technology (PCAST). (2010) Report to the President: Prepare and Inspire: K-12 Education in Science, Technology,Engineering, and Math (STEM) for America's Future. Retrieved from https://obamawhitehouse.archives.gov/sites/default/ files/microsites/ostp/pcast-stemed-execsum.pdf

Stanton-Salazar, R. D., and Spina, S. U. (2005). Adolescent peer networks as a context for social and emotional support. Youth and Society, 36(4), 379-417.

Talpade, M. (2018). The impact of African dance on psychosocial and educational outcomes. Journal of Instructional Pedagogies, 20.

Turkle, S. and Papert, S. (1990). Epistemological pluralism and the reevaluation of the concrete. Journal of Mathematical Behavior, 11(1), 3-33.

Vilorio, D. (2014). STEM 101: Intro to Tomorrow's Jobs. (United States, Department of Labor, Bureau of Labor Statistics). Washington, DC: Bureau of Labor Statistics. Retrieved from https://www.bls.gov/careeroutlook/2014/spring/ art01.pdf 